\title{
PODELITEV PRIZNANJ TOP 10 - IZOBRAŽEVALNI MANAGEMENT 2005
}

L jetos so bila v okviru 5 , tradicionalne konference Izobraževalni management 2005 podeljena priznanja TOP - 10 Izobraževalni management 2005. Na razpis se je prijavilo 17 organizacij in prav vsem gre zahvala za pogum, saj so s tem dokazali, da želijo tekmovati v boju za znanje, in hkrati pokazali, da je čas za akcijo ter da želijo na področju izobraževanja narediti več kot doslej.

Akcijo vsako leto izvaja neodvisni inštitut SOFOS. Namen akcije TOP $10 \mathrm{ni}$ v tem, da bi iskali in našli enega in absolutnega zmagovalca, cilj je, da najdemo več zmagovalcev, torej tistih slovenskih podjetij,

- ki izkazujejo neposredno povezanost izobraževalne in poslovne strategije,

- ki sistematično pridobivajo nova znanja,

- ki omogočajo zaposlenim preizkušanje in širjenje novo pridobljenega znanja,

- ki skrbijo za izobraževanje slehernega zaposlenega

in nam $s$ temi načini ravnanja $z$ zaposlenimi utirajo pot $\mathrm{v}$ ekonomijo znanja.

\section{PREDSTAVITEV KRITERIJEV}

Pri izboru 10 najboljših podjetij je strokovna komisija upoštevala tako kvantitativne kriterije kot tudi kvalitativne. Pri kvalitativnih kriterijih so ocenjevalci preverjali višino finančnih sredstev od skupnih prihodkov podjetja, ki jih podjetja namenjajo izobraževanju zaposlenih, odstotek zaposlenih, vključenih $v$ izobraževanje, in usposabljanje, število ur izobraževanja in usposabljanja na zaposlenega v letu dni, Število oz. odstotek notranjih izobraževalcev, ki prenašajo znanje znotraj podjetja, ter odstotek merjenja kakovosti izobraževalnih izvedb. Med drugimi je komisija upoštevala tudi nekatere kvalitativne kriterije, predvsem povezanost izobraževalne strategije s poslovno strategijo podjetja in vlaganje $v$ izobraževanje v širšem družbenem okolju.

Letos so se med dobitnike priznanj TOP 10 - lzobraževalni management 2005 uvrstila naslednja podjetja, našteta bo abecednem vrstnem redu:

\section{Bolnišnica Golnik,}

2. Gorenje, d. d.,

3. Lek, d. d.,

4. Merkur, d. d.,

5. NLB, d. d.,

6. Poslovna skupina Sava, d. d.,

7. Smart com, d. o, o.,

8. SRC.SI, d. o. o.,

9. Premogovnik Velenje d. d., 10. Zavod RS za zaposlovanje.

Naj omenim, da je šest letošnjih dobitnikov priznanj slavilo tudi prejšnje leto. To so bili Lek, Merkur, Smart Com, SRC.SI, Premogovnik Velenje in Zavod za zaposlovanje. Zelo spodbudno je, da je med dobitniki že dve leti zapored tudi organizacija javnega sektorja, to je Zavod za zaposlovanje, ki tako daje zgled vsemu javnemu sektorju, da se čimprej na področju izobraževalnega menedžmenta približa gospodarstvu. 
Primeriava TOP 10 - Izobraževalni management 2002, 2003, 2004 in 2005

\begin{tabular}{|l|c|c|c|c|}
\hline Kriterij & Leto 2002 & Leto 2003 & Leto 2004 & Leto 2005 \\
\hline $\begin{array}{l}\text { Povprečen \% od prihodkov, namenjen } \\
\text { izobraževanju in usposabljanju }\end{array}$ & 0,66 & 0,98 & 1,51 & 1,11 \\
\hline $\begin{array}{l}\text { Povprečen \% zaposlenih, vključenih v } \\
\text { izobraževanje }\end{array}$ & 80,4 & 89,1 & 93,71 & 87,08 \\
\hline $\begin{array}{l}\text { Povprečno število ur izobraževanja na } \\
\text { zaposlenega }\end{array}$ & 37,89 & 35,74 & 49,09 & 54,99 \\
\hline $\begin{array}{l}\text { Povprečen odstotek notranjih } \\
\text { izobraževalcev }\end{array}$ & 9,37 & 13,81 & 13,58 & 13,45 \\
\hline $\begin{array}{l}\text { Merjenje kakovosti izvedbe izobraževalnih } \\
\text { programov v \% }\end{array}$ & 46,73 & 63,42 & 85,59 & 78,22 \\
\hline
\end{tabular}

Letos je Inštitut Sofos izvedel že četrto analizo zapored, tako da lahko ponovno preverimo napredek na področju skrbi za izobraževanje zaposlenih. V zgornji tabeli lahko opazujemo rezultate vseh štirih let.

Za leto 2005 bi lahko rekli, da je obdobje stabilizacije vlaganj v izobraževanje in usposabljanje zaposlenih, če se seveda trend upadanja vseh kazalcev ne bo nadaljeval tudi v naslednjih letih. Po izjemnem zagonu v letu 2004 namreč beležimo upad vseh kazalcev razen povprečnega števila ur na zaposlenega. Toda sočasno upada tudi število vključenih v izobraževanje, na podlagi česar lahko sklepamo, da se vodstveni kadri izobražujejo več, toda več kot lani jih ostaja brez dostopa do novega znanja. Na področju notranjih izobraževalcev pa praktično zadnja tri leta ostajamo na enaki ravni. Za preboj tega kazalca bo vsekakor treba več narediti za motivacijo notranjih izobraževalcev. V nekaterih organizacijah so ljudje za prenašanje znanja posebej nagrajeni, $v$ nekaterih pa se to šteje kot službena dolžnost.

Letos je organizator podelil tudi posebno priznanje za vlaganje $v$ znanje $v$ širšem družbenem okolju, ki ga je prejela Zavarovalnica Triglav, d. d., in ob tem simbolično darilo Punčko iz cunj, ki predstavlja posebno akcijo Unicefa za cepljenje otrok v manj razvitih deželah. Tudi cepljenje je namreč učenje, učenje telesa, da ob nepredvidljivih in izrednih razmerah aktivira svoje znanje, zato je bila simbolika darila izjemno povezana s celotno akcijo.

Vsem dobitnikom priznanj tudi $v$ naši reviji čestitamo in jih obenem pozivamo, da širijo dobro prakso, vse druge pa vabimo, da se drugo leto priključijo tistim, ki bodo oblikovali in dvigovali standarde na področju izobraževanja, ter da se prijavijo na razpis TOP 10 - Izobraževalni management 2005 , ki bo od meseca julija 2006 odprt na spletnih straneh www.planetgv.si

Mag. Daniela Brečko

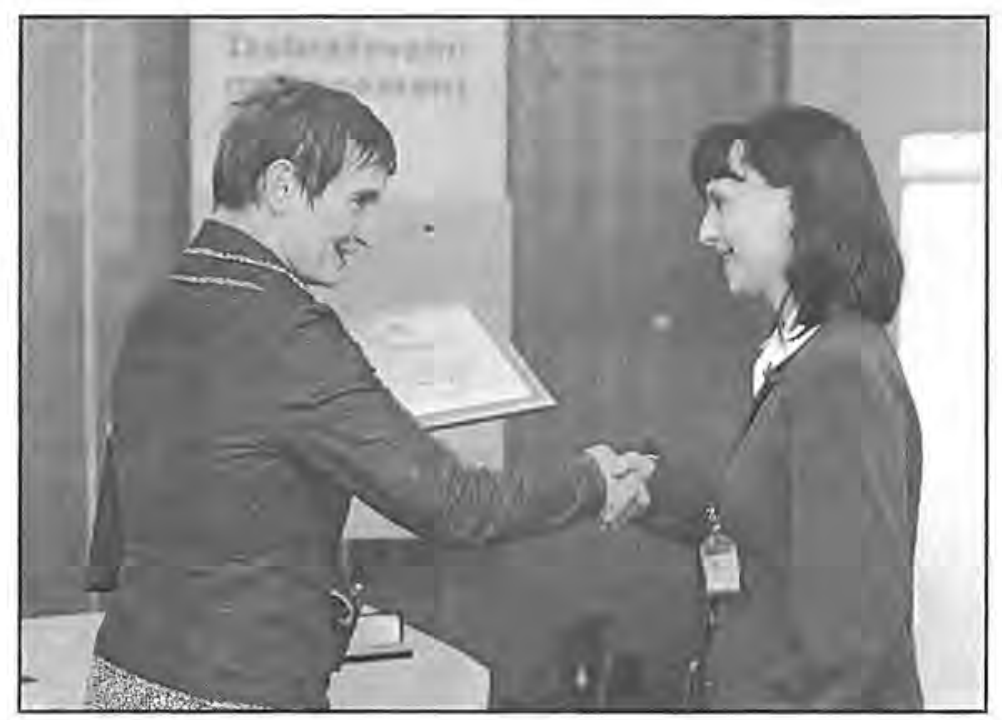

